\title{
Financial prudential behavior and economic growth
}

\section{Comportamiento financiero prudencial y crecimiento económico}

\author{
Salvador Rivas-Aceves, Griselda Dávila-Aragón* \\ Universidad Panamericana, México
}

Received August 21, 2019; accepted September 4, 2020

Available online September 4, 2020

\begin{abstract}
The 2008 global financial crisis showed not only that there is a link between real economy and financial markets, but also that financial stability is necessary for investment, innovation and of course economic growth. Regarding the link between real and financial sectors, several studies long before the 2008 financial crisis revealed positive impacts from financial sector on real economy, basically because a solid financial system promote physic and human capital accumulation, see Banerjee and Newman (1993) Galor and Zeira (1993), Aghion and Bolton (1997), Piketty (1997), Levine (1997), Levine and Zervos (1998), Rajan and Zingales (1998). When considering well-developed financial markets as economic growth promoters the researches of Levine (2005), Aghion et al. (2005) and Acemoglu et al. (2006) proved that financial develop indeed accelerates economic growth.
\end{abstract}

JEL codes: G10, G18, G14, O40, E44

Keywords: Financial market; Regulation; Efficiency of capital market; Economic growth and macroeconomic equilibrium

*Corresponding author.

E-mail address: gdavila@up.edu.mx (G. Dávila Aragón).

Peer Review under the responsibility of Universidad Nacional Autónoma de México. 


\section{Resumen}

En un modelo de crecimiento de equilibrio general estocástico con una economía cerrada y sistema financiero se caracteriza el vínculo entre el sector real y el financiero. Los impactos negativos sobre el crecimiento ocurren cuando el mercado financiero muestra ineficiencias, que pueden corregirse mediante la regulación financiera, realizada por el gobierno a través de un impuesto sobre el rendimiento del capital. Una característica especial del modelo es que el análisis se hace con sectores productivos heterogéneos. Se realizan pruebas empíricas para corroborar los resultados teóricos mediante el uso de técnicas de mínimos cuadrados en un panel de datos definido para 17 países desarrollados y en desarrollo, con información de 1980 a 2017. En particular, son estimados efectos fijos y aleatorios en las especificaciones de sección transversal y temporal, incluyendo modelos pre-crisis, post-crisis y durante todo el intervalo de tiempo, considerando la crisis financiera del 2008 el punto de quiebre. Los principales resultados son: a) existe un vínculo natural entre el sector real y el financiero, b) existe un efecto negativo en el crecimiento debido a la asuencia de reasignaciones de capital, c) las reasignaciones de capital en sectores productivos solo ocurren si la productividad marginal del capital es mayor que los rendimientos del capital en el sistema financiero, d) la regulación financiera del gobierno corrige las ineficiencias financieras y por lo tanto caídas en la tasa de crecimiento económico, e) la regulación financiera se puede realizar aplicando un impuesto sobre el rendimiento del capital, f) la evidencia empírica confirma los resultados teóricos.

Código JEL: G10, G18, G14, O40, E44

Palabras clave: Regulación del mercado financiero; Eficiencia del mercado de capitals; Crecimiento económico y equilibrio macroeconómico

\section{Introduction}

The 2008 global financial crisis showed not only that there is a link between real economy and financial markets, but also that financial stability is necessary for investment, innovation and of course economic growth. Regarding the link between real and financial sectors, several studies long before the 2008 financial crisis revealed positive impacts from financial sector on real economy, basically because a solid financial system promote physic and human capital accumulation, see Banerjee and Newman (1993) Galor and Zeira (1993), Aghion and Bolton (1997), Piketty (1997), Levine (1997), Levine and Zervos (1998), Rajan and Zingales (1998). When considering well-developed financial markets as economic growth promoters the researches of Levine (2005), Aghion et al. (2005) and Acemoglu et al. (2006) proved that financial develop indeed accelerates economic growth.

At an empirical level, some authors explore the impact of a well-developed financial sector on growth by using country-specific or time-series analysis, for example Rousseau 
and Wachtel (1998), Demirgüc-Kunt and Levine (2001), Carlin and Mayer (2003), where particularly requirements for a positive impact on growth are characterized if financial markets are well-developed. Other important studies have proved that further increases in financial development lead to lower economic growth rates, the mechanism behind relies in the idea of financial entities offering a wide set of options to invest, the vast majority being portfolio instruments. Capital would naturally tend to be allocated into these instruments rather than in productive projects, especially when rates of return are higher than in productive sector. If productive projects are less financed, then economic activities decrease, see for instance Arcand et al. (2015), Aizenman et al. (2015) and Loayza et al. (2018). This research line is more closed to this research.

In contrast, studies that argue that credit constraints or any other financial inefficiency can actually inhibit capital accumulation are found; see Benabou (1993, 1996), Durlauf (1996), Fernández and Rogerson (1994, 1996), De Serres et al. (2006), Ulrich (2004) and Sinha (2012).

Because of the financial crisis and based on the academic research described above, it is clear that the financial environment affects economic activities and therefore growth. Hence, several financial regulations have been proposed and most of them are contained in Basel III, for instance banking regulations and supervision, improves on risk management, individual exposures, bank exposures, corporate exposures, capital instruments, real estate transactions, domestic credit, etc. Basel III aims to eliminate possible transmission channels towards real economy if a financial crisis emerges. In this sense, Acharya (2009) points out that in order to mitigate an economic risk due to financial crisis, specific regulatory mechanisms are necessary.

Financial regulation studies have proved that capital markets can be regulated so inefficiencies within financial systems can be eliminated, whit regulations been performed by the government, see Barth, Caprio and Levine (2001a, 2001b, 2004, 2005), Levine (2011), La Porta, Lopez-de-Silanes and Shleifer (2005). More specific forms of regulation that enhance real economic conditions such as bailouts or too-big-to-fail (TBTF) events, fractional reserve banking or capital controls can be found (Barucci et al. 2019, Allen et al. 2018, Chari and Phelan 2014, Devereux et al. 2019).

The objective of this research is to show that eliminating transmission channels between real and financial sectors is not enough in order to avoid negative impacts of financial crisis on economic growth. Low economic growth rates are not generated by financial crisis exclusively even if the financial sector is well-developed or not, but due to a deviation of capital flows throughout financial markets provoked by high capital yields within them. In other words, capitals tend to flow where expected returns are higher and nowadays this usually occurs in financial markets. Therefore productive investment is decreasing in comparison with portfolio investment since recently capital marginal productivity has being lower than capital yields. Specific objectives are to study: i) the link between financial and real sectors, ii) that there 
is negative effect of a inefficient financial sector on economic growth, iii) that this negative effect can be corrected by government regulation, iv) the conditions under which financial regulation is needed.

This research follows the idea that a well-developed financial system facilitates economic activities, provides liquidity, allocates capital to highest-return projects and stimulates specialization (Kivanc and Yildirim, 2019), at the same time that corrects information problems and tends to diminish transaction costs (Levine 1997). On the other hand, a less-developed financial system generates credit constrains, higher costs on financing projects and diminishes the speed at which firms can start a new project (Kivanc and Yildirim, 2019). When there are credit constrains or higher costs on financing, inefficiency appears since allocations of resources in time and space are not happening, in accordance with Merton and Bodie (1995). The theoretical framework being used in the present research is micro-founded, at that level banks could prevent companies to acquire productive credits because high yields, credit constrains, etc. If that is the case, at a macroeconomic level the entire financial system could behave the same. Following Merton and Bodie (1995) ideas, allocations into productive sector not being happening represents itself an inefficiency.

In order to do so a theoretical general equilibrium growth model with a financial system is characterized, where the natural link between real and financial sector is present. Negative impacts on growth when financial market displays inefficiencies are shown, which can be corrected by financial regulation performed by government when applying a capital yield tax. One main feature of the model is that is based on heterogenic productive sectors, for a closed stochastic growing economy. Empirical tests are performed in order to corroborate theoretical results by using LS techniques on a panel data defined for 17 developed and developing countries during the time interval from 1980 to 2017, also fixed and random effects on both cross-section and time period specifications were estimated. Empirical analysis includes pre-crisis, post-crisis and full-time models whit 2008 financial crisis as point of reference.

Main results are: a) there is natural link between real and financial sectors, b) there is negative effect on growth due to a privation of capital reallocations, c) capital reallocations on productive sectors only occurs if marginal productivity of capital is greater than capital yields at financial system, d) government financial regulation corrects financial inefficiencies and therefore falls in the economic growth rate, e) financial regulation can be performed by applying a capital yield tax, f) empirical evidence confirm theoretical results.

This document is organized as follows: in Section 2 the basic theoretical model is developed, and then financial system is introduced in order to define impacts between both sectors (Section 3), thus allows studying financial regulation and its effects on economic growth (Section 4). Finally, empirical evidence is analyzed in Section 5 and both theoretical and empirical results are discussed in Section 6, so conclusions are presented in Section 7. 


\section{Growing Closed Economy}

Consistently with the literature review the following theoretical model is develop to define in first place if there is a link between real and financial sector, then to identify under which conditions the causality can be either positive or negative, and finally how negative impacts on growth can be corrected if they are in place. So consider a usual growing closed economy as proposed by Rivas-Aceves (2012) and Rivas-Aceves and Amato (2017), where households seek to maximize the expected value of their utility due to the consumption of a perishable commodity, this consumption presents decreasing marginal yields and is discounted by the regular subjective rate, decision that consumers perform with all access to necessary information at any time. The correspondent von Neumann-Morgenstern utility function separable at $t=0$ is:

$$
\mathcal{V}_{0}=E\left\{\int_{0}^{\infty} \ln c_{t} e^{-\rho t} d t \mid \mathcal{F}_{0}\right\}
$$

Industry is to produce commodities with all capital available at any time as well, using a given technology, considering both expected average on marginal product of capital and expected productivity dispersion; a leap in marginal product could occur with a intensity so production is modeled by:

$$
\begin{gathered}
d y_{t}=\alpha\left(k_{t} d t+k_{t} \sigma_{y} d W_{t}+k_{t} v_{y} d Z_{t}\right), \\
\left\{\begin{array}{l}
\operatorname{Pr}(\text { a leap during } d t)=\operatorname{Pr}\left(d Z_{t}=1\right)=\theta_{y} d t, \\
\operatorname{Pr}(\text { none leap during } d t)=\operatorname{Pr}\left(d Z_{t}=0\right)=1-\theta_{y} d t+o(d t), \\
\operatorname{Pr}(\text { more than one leap during } d t)=\operatorname{Pr}\left(d Z_{t}>1\right)=o(d t) .
\end{array}\right.
\end{gathered}
$$

These leaps can take place due to salary policies, labor training, technological innovation, etc. and can be present in short besides long term. From a macroeconomic point of view household own all production means so global product is intended to investment or consumption,

$$
d y_{t}=d k_{t}+c_{t} d t
$$

Substituting equation (3) in (7) causes the capital accumulation dynamics in the economy involving available information at $t=0$ given by $\mathcal{F}_{0}=\left\{k_{0}, Z_{0}\right\}$.

$$
d k_{t}=k_{t}\left(\alpha-\frac{c_{t}}{k_{t}}\right) d t+k_{t} \alpha \sigma_{y} d W_{t}+k_{t} \alpha v_{y} d Z_{t}
$$

When macroeconomic equilibrium is in place, capital and consumption dynamics react because of movements on marginal procduct and consumption preferences over time, see equations 9 and 10 . 


$$
\begin{gathered}
k_{t}=k_{0} e^{\left(\alpha-\rho-\frac{\alpha^{2} \sigma_{y}^{2}}{2}\right) t+\alpha \sigma_{y} W_{t}+\ln \left(1+\alpha v_{y}\right) z_{t}}, \\
c_{t}=\rho k_{0} e^{\left(\alpha-\rho-\frac{\alpha^{2} \sigma_{y}^{2}}{2}\right) t+\alpha \sigma_{y} W_{t}+\ln \left(1+\alpha v_{y}\right) z_{t}},
\end{gathered}
$$

The economic growth rate on this economy depends on how capital accumulation rises and how current consumption falls. Particularly, increases on the expected average of marginal product of capital or on the intensity marginal product leaps have a positive effect on economic growth rate, since:

$$
\Psi=E\left[\frac{d k_{t}}{k_{t}} \cdot \frac{1}{d t}\right]=\alpha+\alpha v_{y} \theta_{y}-\rho .
$$

Meanwhile, variability in growth rate depends on marginal product of capital variability and the leap variance since the variability in the deterministic component of growth rate is:

$$
E\left[\frac{d k_{t}}{k_{t}}\right]^{2}=\alpha^{2}\left(\sigma_{y}^{2}+v_{y}^{2} \theta_{y}\right) d t .
$$

The above equation shows that each temporary increase in the economy will directly affect the stochastic standard deviation of growth rate.

\section{Growing Economy with Financial Sector}

According with this model, financial sector is to guide funds from economic agents that registered surpluses in the past due to their economic activities towards those that have registered deficits. Therefore two types of households divide total population in this economy: lenders $(l)$ and borrowers $(b)$, both are part of the industry and are constant over time. In addition to what the authors propose let's assume per capita stock of capital to be constitute by physical capital and financial capital in the sense that financial sector does reassign idle resources within productive sector, but also hold them to invest into stock exchange due to an economic agent's request. Consequently, total capital in the economy is extended in this analysis in comparison with Rivas-Aceves and Amato (2017) proposal as follows:

$$
\begin{aligned}
& K_{t}=k_{t}^{b}+k_{t}^{l}, \\
& k_{t}^{l}=k_{t}+\tilde{k}_{t}\left(d R_{k}+d I_{k}\right),
\end{aligned}
$$


Where $k_{t}$ stands for the capital needed to produce, $\tilde{k}_{t}$ measures a surplus of capital with $\tilde{k}_{0}>0, d R_{k}$ measures capital yield when resources are reassigned within industry which also represents the credit's cost to the borrower agent, and $d l_{k}$ measures capital yield when resources are invested into stock markets. Equation (14) allows defining two options of investments for lender sector thus amplifying the roll of the financial system in comparison with Rivas-Aceves and Amato (2017) proposal. Consequently the stock of capital $K_{t}$ in this economy is considering physical and financial dimensions of it. Regarding capital behavior all original assumptions remain and a new one comes up since a lender producer would prefer to invest in stock markets rather than industry when $d R_{k}<d I_{k}$. Dynamics of both credit's cost and capital yield are:

$$
\begin{gathered}
d R_{k}=\frac{d \tilde{k}_{t}}{\tilde{k}_{t}}=\delta\left(d t+\sigma_{\delta} d X_{t}+v_{\delta} d Q_{t}\right) \\
d I_{k}=\frac{d \tilde{k}_{t}}{\tilde{k}_{t}}=\gamma\left(d t+\sigma_{\gamma} d P_{t}+v_{\gamma} d S_{t}\right) \\
\left\{\begin{array}{l}
\operatorname{Pr}(\text { a leap during } d t)=\operatorname{Pr}\left(d Q_{t}, d S_{t}=1\right)=\theta_{\delta} d t, \theta_{\gamma} d t \\
\operatorname{Pr}(\text { none leap during } d t)=\operatorname{Pr}\left(d Q_{t}, d S_{t}=0\right)=1-\theta_{\delta} d t-\theta_{\gamma} d t+o(d t), \\
\operatorname{Pr}(\text { more than a leap during } d t)=\operatorname{Pr}\left(d Q_{t}, d S_{t}>1\right)=o(d t)
\end{array}\right.
\end{gathered}
$$

Now capital accumulation in the economy is determined by:

$$
\begin{gathered}
d k_{t}^{l}=k_{t}^{l}\left(\alpha+\delta+\gamma-\frac{c_{t}^{l}}{k_{t}^{l}}\right) d t+k_{t}^{l}\left(\alpha \sigma_{y}+\delta \sigma_{\delta}+\gamma \sigma_{\gamma}\right) d U_{t}^{l} \\
+k_{t}^{l}\left(\alpha v_{y}+\delta v_{\delta}+\gamma v_{\gamma}\right) d M_{t}^{l} \\
d k_{t}^{b}=k_{t}^{b}\left(\alpha-\delta-\frac{c_{t}^{b}}{k_{t}^{b}}\right) d t+k_{t}^{b}\left(\alpha \sigma_{y}-\delta \sigma_{\delta}\right) d U_{t}^{b}+k_{t}^{b}\left(\alpha v_{y}-\delta v_{\delta}\right) d M_{t}^{b}
\end{gathered}
$$

Accumulation for the physical dimension in capital is measured by the first term and accumulation for the financial dimension by the remaining terms, in both equations (20) and (21). Up to this point, all Wiener processes $\left(d W_{t}, d X_{t}, d P_{t}, d U_{t}^{l}, d U_{t}^{b}\right)$ are defined in a fixed probability space with an augmented filtration $\left(\Omega, F,\left(F_{t}\right)_{t \geq 0}, \mathbb{P}\right)$, with independent temporary increases. All Poisson processes $\left(d Z_{t}, d Q_{t}, d S_{t}, d M_{t}^{l}, d M_{t}^{b}\right)$ are uncorrelated to each other; initial number of leaps in all of them is zero. Both economic restrictions (20) and (21) meet with $\mathcal{F}_{0}=\left\{c_{0}, k_{0}, \tilde{k}_{0}, Z_{0}, W_{0}, X_{0}, Q_{0}, P_{0}, U_{0}, S_{0}, M_{0}\right\}$ simultaneously.

Hence, macroeconomic equilibrium depends on lender and borrower sectors, which consider the financial information into their economic decisions. Regarding lender sector, 
the equilibrium is based on movements on productivity and consumption preferences, both capitals yields and volatilities and jumps on them, as shown in (22), (23) and (24).

$$
\begin{aligned}
k_{t}^{l} & =k_{0}^{l} e^{\left(\alpha+\delta+\gamma-\rho-\frac{\Gamma}{2}\right) t+(\Xi) U_{t}^{l}+(\Omega) M_{t},} \\
c_{t}^{l} & =\rho k_{0}^{l} e^{\left(\alpha+\delta+\gamma-\rho-\frac{\Gamma}{2}\right) t+(\Xi) U_{t}^{l}+(\Omega) M_{t},} \\
\psi^{l} & =\left(\alpha+\delta+\gamma-\rho-\frac{\Gamma}{2}\right) t+(\Xi) U_{t}^{l}+(\Omega) M_{t}, \\
\Gamma & =\alpha^{2} \sigma_{y}^{2}+\delta^{2} \sigma_{\delta}^{2}+\gamma^{2} \sigma_{\gamma}^{2}, \\
\Xi & =\alpha \sigma_{y}+\delta \sigma_{y}+\gamma \sigma_{\gamma}, \\
\Omega & =\ln \left(1+\alpha v_{y}\right)+\ln \left(1+\delta v_{\delta}\right)+\ln \left(1+\gamma v_{\gamma}\right) .
\end{aligned}
$$

As it can be noticed, lender's equilibrium depends on the allocation of capital surplus between industry or stock markets, or allocations in both. Meanwhile borrower sector reacts by movements on productivity and consumption preferences and the credit's cost including its volatility and jumps, as shown in (28), (29) and (30).

$$
\begin{aligned}
k_{t}^{b} & =k_{0}^{b} e^{\left(\alpha-\delta-\rho-\frac{\Upsilon}{2}\right) t+(\Phi) U_{t}^{l}+(\Sigma) M_{t}}, \\
c_{t}^{b} & =\rho k_{0}^{b} e^{\left(\alpha-\delta-\rho-\frac{\Upsilon}{2}\right) t+(\Phi) U_{t}^{l}+(\Sigma) M_{t}}, \\
\psi^{b} & =\left(\alpha-\delta-\rho-\frac{\Upsilon}{2}\right) t+(\Phi) U_{t}^{l}+(\Sigma) M_{t}, \\
\Sigma & =\ln \left(1+\alpha v_{y}\right)-\ln \left(1+\delta v_{\delta}\right), \\
\Upsilon & =\alpha^{2} \sigma_{y}^{2}-\delta^{2} \sigma_{\delta}^{2} \\
\Phi & =\alpha \sigma_{y}-\delta \sigma_{y} .
\end{aligned}
$$

The corresponding economic growth rate is defined by the average growth of both productive sectors: lender and borrower. By considering equations (24) and (30), the deterministic component of growth is:

$$
\begin{gathered}
\Psi=\frac{\psi^{l}+\psi^{b}}{2}=\frac{E\left[\frac{d k_{t}^{l}}{k_{t}^{l}} \cdot \frac{1}{d t}\right]+E\left[\frac{d k_{t}^{b}}{k_{t}^{b}} \cdot \frac{1}{d t}\right]}{2} \\
=\frac{\left(\alpha+\delta+\gamma+\alpha v_{y} \theta_{y}+v_{\delta} \theta_{\delta}+v_{\gamma} \theta_{\gamma}-\rho\right)+\left(\alpha+\alpha v_{y} \theta_{y}-v_{\delta} \theta_{\delta}-\delta-\rho\right)}{2} .
\end{gathered}
$$


Equivalently,

$$
\Psi=\alpha+\gamma+\alpha v_{y} \theta_{y}+v_{\gamma} \theta_{\gamma}-\rho .
$$

The growth rate of this economy will be positive if $\alpha+\gamma+\alpha v_{y} \theta_{y}+v_{\gamma} \theta_{\gamma}>\rho$ since marginal productivity of capital, capital yield and leaps from both have a positive impact on it. On the other hand, variability in growth relays on marginal productivity of capital variability and its leaps as well as on capital yield volatility and its leaps, as equation (36) shows:

$$
E\left[\frac{d k_{t}}{k_{t}}\right]^{2}=\left[\alpha^{2}\left(\sigma_{y}^{2}+v_{y}^{2} \theta_{y}\right)+\gamma^{2}\left(\sigma_{\gamma}^{2}+v_{\gamma}^{2} \theta_{\gamma}\right)\right] d t .
$$

So economic growth path could be higher than the expected trend if the positive side of volatility were in place, nevertheless would be lower when the negative side is present. Similar behaviors on leaps will have the same impacts on growth. However, volatility within financial markets is not the only source of lower growth, credits constrains can also generate slow growth. What if borrower sector is not taking place in economic activities due to insufficient capital? Lender producer can decide to allocate his entire capital surplus into stock markets leaving no resources to credit market; can also ask for a high return on capital destined to productive credits as a respond for a high risk, in other words having a degree of aversion to lend; in any case is to accomplish $\tilde{k}_{t}\left(1+d R_{k}\right)-c_{t}^{b} d t \geq \alpha\left(d t+\sigma_{y} d W_{t}+v_{y} d Z_{t}\right)$ on borrowers. If any of these two scenarios happen, then growth rate will be:

$$
\Psi=\frac{\alpha+\gamma+\alpha v_{y} \theta_{y}+v_{\gamma} \theta_{\gamma}-\rho}{N^{l}},
$$

with $N^{l}$ being the population size of lenders. Obviously, the economic growth rate established in (37) is lower than in (35). It is in this case when financial system has a negative effect on growth. It is really important to highlight that basic economic activity for any type of firm is to produce, as it was defined at the beginning, therefore all firms are assumed to prioritize production decisions; it could be easily misunderstood the fact that borrowers are not producing because they decide not to borrow capital. Even further, borrower sector needs to produce in order to be able to consume. So, if they want to produce, the only reason why they are not getting credits is because the credit cost is too high to be paid. Accordingly, an excessive increase in capital cost caused by credit constraints or inefficiencies in the financial system generates disincentives in the productive sector and thus creates a fall in economic growth rate, as well as unemployment of production factors. 


\section{Financial Regulation}

Regulation would be necessary if capital cost is so high that capital accumulation in borrower sector becomes zero or negative in order to avoid a fall in the growth rate. The following condition must be met:

$$
d y_{t}^{b}-\tilde{k}_{t}\left(1+d R_{k}\right)-c_{t}^{b} d t>0 .
$$

Clearing for the cost of capital:

$$
d R_{k}<\frac{d y_{t}^{b}-c_{t}^{b} d t}{k_{t}^{b}}-1
$$

Considering equilibrium conditions (28) - (33) into (39):

$$
d R_{k}<\alpha\left(d t+\sigma_{y} d W_{t}+v_{y} d Z_{t}\right)-\rho-1 .
$$

Borrower sector remains dependent of credit cost, as was assumed, for participating in economic activities. That is, capital cost needs to be lower than the expected average of marginal product of capital for the borrower producer for production process to be on in the sector. However, lender sector will allocate capital as a productive credit if capital productivity is higher than capital yields. By analyzing deterministic and stochastic components that will be:

$$
\begin{aligned}
& \left(\delta+\delta \theta_{\delta}+\gamma \theta_{\gamma}\right) d t<\left(\alpha+\alpha \theta_{y}\right) d t \\
& \left(\delta \sigma_{\delta}+\gamma \sigma_{\gamma}\right) d X_{t}<\alpha \sigma_{y} d W_{t} . \\
& \left(\delta^{2} \sigma_{\delta}^{2}+\gamma^{2} \sigma_{\gamma}^{2}\right) d t<\alpha^{2} \sigma_{y}^{2} d t .
\end{aligned}
$$

The later scenario would be possible if markets conditions meet capital productivity being higher than capital yields, if not only financial regulation will meet them. If that were the case, then physical capital accumulation would be higher than financial capital accumulation, thus leading to higher growth rates in economic activities. Let's assumed regulation is taking care of by government as the form of a tax that can be imposed at any time, on capital yields in order to accomplish:

$$
\tau_{\delta, \gamma}\left[\left(\delta+\delta \theta_{\delta}+\delta^{2} \sigma_{\delta}^{2}\right)+\left(\gamma+\gamma \theta_{\gamma}+\gamma^{2} \sigma_{\gamma}^{2}\right)\right] d t \geq\left(\alpha+\alpha \theta_{y}+\alpha^{2} \sigma_{y}^{2}\right) d t-\rho-1 .
$$

For simplicity lest assume government does not carry out any other activity so its budget constraint is:

$$
g d t=\tau_{\delta, \gamma} .
$$


Being per capita expected average spending of government as production subsidies exclusively directed to borrower sector. Regulations will only take place if there are excessive increases on capital/credit cost.

On lenders side, tax cannot be such that causes capital accumulation to be zero or negative in the sector. Otherwise, growth rate would be lower, so:

$$
d y_{t}^{l}+\tilde{k}_{t}\left(1+d R_{k}+d I_{k}\right)-\tau_{\delta, \gamma} \tilde{k}_{t}\left(d R_{k}+d I_{k}\right)-c_{t}^{l} d t>0 .
$$

Considering equilibrium conditions (22) - (27) into (46):

$$
\tau_{\delta, \gamma}<\frac{\left(\alpha+\delta+\gamma+\alpha \theta_{y}+\delta \theta_{\delta}+\gamma \theta_{\gamma}+\alpha^{2} \sigma_{y}^{2}+\delta^{2} \sigma_{\delta}^{2}+\gamma^{2} \sigma_{\gamma}^{2}\right) d t+1-\rho}{\left(\delta+\gamma+\delta \theta_{\delta}+\gamma \theta_{\gamma}+\delta^{2} \sigma_{\delta}^{2}+\gamma^{2} \sigma_{\gamma}^{2}\right) d t} .
$$

Consequently, the optimal behavior for tax is defined by equations (40) and (47) as follows:

$$
\begin{aligned}
\frac{\alpha+\alpha \theta_{y}+\alpha^{2} \sigma_{y}^{2}-\rho-1}{\mathrm{E}} & \leq \tau_{\delta}<\frac{\alpha+\alpha \theta_{y}+\alpha^{2} \sigma_{y}^{2}+\mathrm{A}+\mathrm{B}+1-\rho}{\mathrm{A}+\mathrm{B}}, \\
\mathrm{A} & =\delta+\gamma+\delta \theta_{\delta}+\gamma \theta_{\gamma} \\
\mathrm{B} & =\delta^{2} \sigma_{\delta}^{2}+\gamma^{2} \sigma_{\gamma}^{2} \\
\mathrm{E} & =\delta+\delta \theta_{\delta}+\delta^{2} \sigma_{\delta}^{2} .
\end{aligned}
$$

Where A measures the expected average of both capital yields, the volatility on both capita yields and the expected average of capital/credit cost. Under these circumstances, the equilibrium conditions change since capital accumulation equations of both sectors have been modified:

$$
\begin{gathered}
\frac{\mathrm{dk}_{\mathrm{t}}^{1}}{\mathrm{k}_{\mathrm{t}}^{\mathrm{l}}}=\alpha\left(\mathrm{dt}+\sigma_{\mathrm{y}} \mathrm{dW} \mathrm{W}_{\mathrm{t}}+\mathrm{v}_{\mathrm{y}} \mathrm{dZ_{ \textrm {t } }}\right)+\tilde{\mathrm{k}}_{\mathrm{t}}\left(1+\mathrm{dR}_{\mathrm{k}}+\mathrm{dI}_{\mathrm{k}}\right)-\tau_{\delta, \gamma} \tilde{\mathrm{k}}_{\mathrm{t}}\left(\mathrm{dR}_{\mathrm{k}}+\mathrm{dI}_{\mathrm{k}}\right)-\mathrm{c}_{\mathrm{t}}^{\mathrm{l}} \mathrm{dt},\left(52, \mathrm{dk}_{\mathrm{t}}^{\mathrm{b}}=\alpha\left(\mathrm{dt}+\sigma_{\mathrm{y}} \mathrm{d} \mathrm{W}_{\mathrm{t}}+v_{\mathrm{y}} \mathrm{dZ_{ \textrm {t } }}\right)+\mathrm{gdt}-\tilde{\mathrm{k}}_{\mathrm{t}}\left(1+\mathrm{dR}_{\mathrm{k}}\right)-\mathrm{c}_{\mathrm{t}}^{\mathrm{b}} \mathrm{dt} .\right. \\
\mathrm{k}_{\mathrm{t}}^{\mathrm{b}}=\alpha
\end{gathered}
$$

Thus, deterministic economic growth rate is:

$$
\Psi=\frac{E\left[\frac{\mathrm{dk}_{\mathrm{t}}^{\mathrm{l}}}{\mathrm{k}_{\mathrm{t}}^{\mathrm{l}}} \cdot \frac{1}{\mathrm{dt}}\right]+\mathrm{E}\left[\frac{\mathrm{d \textrm {k } _ { \mathrm { t } } ^ { \mathrm { b } }}}{\mathrm{k}_{\mathrm{t}}^{\mathrm{b}}} \cdot \frac{1}{\mathrm{dt}}\right]}{2}=\alpha+\alpha v_{\mathrm{y}} \theta_{\mathrm{y}}-\rho-\frac{\tau_{\delta, \gamma}\left(\delta+v_{\delta} \theta_{\delta}+\gamma+v_{\gamma} \theta_{\gamma}\right)-\mathrm{g}}{2}(54)
$$

While variability in economic growth rate is:

$$
\mathrm{E}\left[\frac{\mathrm{dk}_{\mathrm{t}}}{\mathrm{k}_{\mathrm{t}}}\right]^{2}=\left[\alpha^{2}\left(\sigma_{\mathrm{y}}^{2}+v_{\mathrm{y}}^{2} \theta_{\mathrm{y}}\right)-\tau_{\delta, \gamma}^{2}\left[\left(\delta^{2}+\gamma^{2}\right)+\left(\sigma_{\delta}^{2}+v_{\delta}^{2} \theta_{\delta}\right)\right]+\mathrm{g}^{2}\right] \mathrm{dt} .
$$


Capital yields and their volatilities have a negative impact on economic growth; this impact can only be compensated by production subsidies to borrower sector when financial regulation takes place. If lender sector exclusively allocates its resources as a productive credit, the expected average of economic growth on (54) will be defined by $\alpha+\alpha v_{y} \theta_{y}-\rho$, which is the same as in (11). Otherwise, economic growth will be determinated by regulation and its magnitud with a positive impact since:

$$
\begin{gathered}
\frac{\partial \Psi}{\partial \mathrm{g}}>0, \\
\frac{\partial \Psi}{\partial \mathrm{g}^{2}}>0 .
\end{gathered}
$$

As summary, the highest economic growth rate possible corresponds to an economy without inefficient financial markets based on Merton and Bodie (1995) idea, where all unemployed resources are natural reallocated by all markets. The second highest growth rate would be the one financial regulation produces since financial markets prevent capital to be allocated at productive sectors. Finally the lowest growth rate will be the one in which capital allocation is such that borrower sector does not participate in economic activities. Under the scenario described above it is easy to see that any financial inefficiency (identified by credit constrains, high volatilities on capital yields or high credit costs) will result on low economic growth rates. Even more, a low economic growth rate can be produced due to a lack of productive credit (productive investment) because capital flows prefer to be allocated at financial system since capital yields are higher than marginal productivity. Without a financial crisis, low economic growth can be still generated by financial sector. Problem that can be solved by a regulation performed thru government.

\section{Empirical Evidence}

In order to analyze if the theoretical model described above is consistent with reality, a panel data was estimated by using information of World Bank (2019) from 17 selected developed and developing countries, during the time interval $1980-2017$. Particularly, the negative impact of financial system on economic growth rate is tested. The selection on countries obeys to whether an efficient financial market is present or not within that economy, so that

\begin{tabular}{|c|c|c|c|c|c|}
\hline - Australia & • Canada & • China & - Costa Rica & • Egypt & - Germany \\
\hline Honduras & - Japan & - Malaysia & - Mexico & - Nigeria & - Singapore \\
\hline Switzerland & - Thailand & - United Kingdom & • Uruguay & - United States & \\
\hline
\end{tabular}
a balanced sample of countries is used in that sense, which is compose by: 
The hypothesis that stands that further increases in financial development lead to lower economic growth rates, see Arcand et al. (2015), Aizenman et al. (2015) and Loayza et al. (2018), is the key to understand why a country balanced sample was needed regarding on financial development. For instance the financial system in countries like Honduras, Costa Rica, México, Nigeria, Thailand, Uruguay and Egypt is not well-developed, therefore credit constrains and other financial inefficiencies are common to see so negative impacts on economic activities are more likely to occur. On the other hand, Australia, Switzerland, Canada, Japan, China, United Kingdom, United States, Germany and Singapore they do have a we1l-developed financial system hence negative impact on economic activities are less likely.

By considering all of them, the natural bias of a not well/well developed financial system on results is avoided. Imagine if exclusively a country sample of a well-developed financial system is used then would be normal to expect a positive causal relation between financial and real variables. Also would be normal to expect a negative relation between them if a country sample of a not well-developed financial system is used. Other characteristics like size, institutional environment, regulatory framework and financial/economic penetration are taking into account in order to select the country. These 17 countries represent a heterogenic sample in that sense. Even more, results turned out to be more robust since this country sample was used for a pre-crisis/post-crisis/full-period analysis, which will be defined in detail latter on.

When analyzing empirical relations between finance and growth several identification methods have been studied and the most common is with the use of a panel data (Beck 2009). In this empirical test by using LS techniques on a panel data the economic growth rate $(G)$ of real GDP is estimated by depending on a set of financial indicators such as: real interest (R), active interest (AI), deposits interest (DI), risk premium of loans (RP), domestic credit (DC) and domestic credit to private sector (DCP). These variables were selected for being the more likely to match the ones defined in the theoretical model. For instance $\mathrm{R}$ is well known to be equal to the marginal product of capital, while AI, DI, RP, DC and DCP would be representing parameters in which financial capital accumulation rely on; they are also a measure for the presence of inefficiencies within financial markets. Estimations are control by savings $(\mathrm{S})$ and fixed capita formation $(\mathrm{K})$ throughout the following equation:

$$
\mathrm{G}_{i t}=\beta_{0}+\beta_{1} F_{i t}+\beta_{2} C_{i t}+\mu_{i t}
$$

Where stands for the financial indicators set, the control variables set and the error term. As equations (35) and (36) define, financial indicators are expected to have negative effects on economic growth. Control variables are selected as possible enhancers on the causal relation between financial indicators and growth. Time period analyze was performed by considering 2008 financial crisis as a break point over a pre-crisis estimation model (1980-2007), 
post-crisis model (2008-2017) and a full-period one. Following Barucci et al. (2019), fixed and random effects were incorporated to estimations on both cross-section and time period analysis in which case the estimation equations is:

$$
\mathrm{G}_{i t}=\beta_{0}+\beta_{i}+\beta_{t}+\beta_{1} F_{i t}+\beta_{2} C_{i t}+\mu_{i t}
$$

Where $\beta_{i}$ measures the country fixed/random effects and $\beta_{t}$ the time fixed/random effects. Results are presented regarding significant estimations only. The use of fixed/random effects incorporate robust estimations for dynamic panels which also controls for potential endogeneity, reverse causality or omission of pertinent variables, according to Blundell and Bond's (1998) and Nickell (1981). Model specifications are verified by Wald test in the sense if additional variables from a simple model enhances the fit by having simultaneously parameter values being significantly different from zero; while Fixed versus Random Effects specifications by Hausman test for knowing whether Random specification is better than Fixed one.

Table 1 show that domestic credit and domestic credit to private sector have a negative impact on economic growth when individual impacts are estimated on the full-period panel data. If simultaneously impacts are taken into account then active interest, domestic credit and domestic credit to private sector inhibit growth. Since these financial indicators are considered as proxy variable of what in the theoretical model was defined as capital yields, therefore the results clearly corroborate the causal relation described at the theoretical model.

When fixed effects on both cross-section and time are incorporated into the estimations, real interest, active interest, deposits interest and domestic credit lead to a less economic growth, as Table 2 shows. On the other hand, if random effects on both cross-section and time are estimated, then the negative impact on growth only comes from active interest and domestic credit. Under this scenario, domestic credit is not enough to promote growth while active interest and deposits interest (capital yields in the theoretical model) obstruct economic growth.

When considering a pre-crisis model results show that active interest, domestic credit, deposit interest and domestic credit to private sector have a negative effect on growth individually. Same casual relation is found when a multiple model is calculated, even more real interest turned to have a negative impact as well, see Table 3. 
Table 1

Full-period panel data ordinary estimation

\begin{tabular}{|c|c|c|c|c|c|c|c|}
\hline $\mathrm{G}$ & I & II & III & IV & V & VI & VII \\
\hline $\mathrm{c}$ & $\begin{array}{c}0.0230 \\
(0.3997)\end{array}$ & $\begin{array}{l}-0.2643 \\
(0.3997)\end{array}$ & $\begin{array}{c}0.9238 \\
(0.3716)^{* * *}\end{array}$ & $\begin{array}{c}0.1172 \\
(0.4283)\end{array}$ & $\begin{array}{l}-0.0225 \\
(0.5161)\end{array}$ & $\begin{array}{c}0.5872 \\
(0.3656)^{*}\end{array}$ & $\begin{array}{c}4.6878 \\
(0.6677)^{* * * *}\end{array}$ \\
\hline $\mathrm{R}$ & $\begin{array}{c}0.0396 \\
(0.0170)^{* * *}\end{array}$ & & & & & & $\begin{array}{c}0.0221 \\
(0.0331)\end{array}$ \\
\hline AI & & $\begin{array}{c}0.0130 \\
(0.0075)^{*}\end{array}$ & & & & & $\begin{array}{c}-0.2091 \\
(0.0603)^{* * * *}\end{array}$ \\
\hline DC & & & $\begin{array}{c}-0.0107 \\
(0.0014)^{* * *}\end{array}$ & & & & $\begin{array}{c}-0.0141 \\
(0.0074)^{* * *}\end{array}$ \\
\hline DI & & & & $\begin{array}{c}0.0047 \\
(0.0116)\end{array}$ & & & $\begin{array}{c}0.1305 \\
(0.0751)^{* *}\end{array}$ \\
\hline $\mathrm{RP}$ & & & & & $\begin{array}{c}0.0644 \\
(0.0178)^{* * *}\end{array}$ & & $\begin{array}{c}0.2695 \\
(0.0656)^{* * *}\end{array}$ \\
\hline DCP & & & & & & $\begin{array}{c}-0.0122 \\
(0.0019)^{* * * *}\end{array}$ & $\begin{array}{l}-0.0077 \\
(0.0066)\end{array}$ \\
\hline$S$ & $\begin{array}{c}0.0475 \\
(0.0177)^{* * *}\end{array}$ & $\begin{array}{c}0.0262 \\
(0.0161)^{*}\end{array}$ & $\begin{array}{c}0.0301 \\
(0.0149)^{* *}\end{array}$ & $\begin{array}{c}0.0183 \\
(0.0172)\end{array}$ & $\begin{array}{c}0.0526 \\
(0.0188)^{* * *}\end{array}$ & $\begin{array}{c}0.0341 \\
(0.0153)^{* *}\end{array}$ & $\begin{array}{c}0.0641 \\
(0.0186)^{* * *}\end{array}$ \\
\hline K & $\begin{array}{c}0.1006 \\
(0.0238)^{* * *}\end{array}$ & $\begin{array}{c}0.1314 \\
(0.0226)^{* * * *}\end{array}$ & $\begin{array}{c}0.1359 \\
(0.0211)^{* * * *}\end{array}$ & $\begin{array}{c}0.1311 \\
(0.0237)^{* * *}\end{array}$ & $\begin{array}{c}0.0809 \\
(0.0298)^{* * * *}\end{array}$ & $\begin{array}{c}0.1404 \\
(0.0212)^{* * * *}\end{array}$ & \\
\hline Obs & 543 & 578 & 570 & 535 & 385 & 582 & 276 \\
\hline
\end{tabular}

Source: Own elaboration. $* * *$ significance $<0.01$; $* *$ significance $<0.05$; $*$ significance $<0.10$ 
Table 2

Full-period panel data with effects

\begin{tabular}{|c|c|c|c|c|c|}
\hline & Cross-section & Period & Cross-section and Period & Cross-section & Period \\
\hline & Fixed Effects & Fixed Effects & Fixed effects & Random Effects & Random Effects \\
\hline $\mathrm{c}$ & $\begin{array}{c}7.5326 \\
(1.6536)^{* * *}\end{array}$ & $\begin{array}{c}3.6442 \\
(0.9772)^{* * *}\end{array}$ & $\begin{array}{c}9.7878 \\
(1.5917)^{* * *}\end{array}$ & $\begin{array}{c}5.5402 \\
(1.3207)^{* * *}\end{array}$ & $\begin{array}{c}3.9608 \\
(0.9305)^{* * *}\end{array}$ \\
\hline $\mathrm{R}$ & $\begin{array}{c}-0.0098 \\
(0.0321)\end{array}$ & $\begin{array}{c}0.0199 \\
(0.0349)\end{array}$ & $\begin{array}{c}0.0003 \\
(0.0310)\end{array}$ & $\begin{array}{c}-0.0042 \\
(0.0317)\end{array}$ & $\begin{array}{c}0.0080 \\
(0.0328)\end{array}$ \\
\hline AI & $\begin{array}{l}-0.1025 \\
(0.0772)\end{array}$ & $\begin{array}{c}-0.2279 \\
(0.0687) * * *\end{array}$ & $\begin{array}{c}-0.2106 \\
(0.0728)^{* * *}\end{array}$ & $\begin{array}{c}-0.1175 \\
(0.0715)^{* *}\end{array}$ & $\begin{array}{c}-0.1627 \\
(0.0639) * * *\end{array}$ \\
\hline DC & $\begin{array}{c}-0.0416 \\
(0.0163)^{* * *}\end{array}$ & $\begin{array}{c}-0.0227 \\
(0.0069) * * *\end{array}$ & $\begin{array}{c}-0.0534 \\
(0.0159) * * *\end{array}$ & $\begin{array}{c}-0.0276 \\
(0.0111)^{* * *}\end{array}$ & $\begin{array}{c}-0.0185 \\
(0.0065)^{* * *}\end{array}$ \\
\hline DI & $\begin{array}{l}-0.0109 \\
(0.1077)\end{array}$ & $\begin{array}{c}-0.1595 \\
(0.0993)^{*}\end{array}$ & $\begin{array}{c}0.2022 \\
(0.1051)^{* *}\end{array}$ & $\begin{array}{c}0.0027 \\
(0.1001)\end{array}$ & $\begin{array}{c}0.0481 \\
(0.0893)\end{array}$ \\
\hline $\mathrm{RP}$ & $\begin{array}{c}0.1461 \\
(0.0665) * * *\end{array}$ & $\begin{array}{c}0.2887 \\
(0.0670)^{* * *}\end{array}$ & $\begin{array}{c}0.2281 \\
(0.0629)^{* * *}\end{array}$ & $\begin{array}{c}0.1817 \\
(0.0651)^{* * *}\end{array}$ & $\begin{array}{c}0.2488 \\
(0.0644) * * *\end{array}$ \\
\hline DCP & $\begin{array}{c}0.0205 \\
(0.0170)\end{array}$ & $\begin{array}{c}0.0044 \\
(0.0096)\end{array}$ & $\begin{array}{c}0.0130 \\
(0.0169)\end{array}$ & $\begin{array}{c}0.0084 \\
(0.0139)\end{array}$ & $\begin{array}{l}-0.0018 \\
(0.0089)\end{array}$ \\
\hline$S$ & $\begin{array}{c}-0.0754 \\
(0.0462)^{*}\end{array}$ & $\begin{array}{l}-0.0215 \\
(0.0309)\end{array}$ & $\begin{array}{c}-0.1797 \\
(0.0465) * * *\end{array}$ & $\begin{array}{c}-0.0322 \\
(0.0389)\end{array}$ & $\begin{array}{c}0.0048 \\
(0.0287)\end{array}$ \\
\hline K & $\begin{array}{c}0.0620 \\
(0.0400)\end{array}$ & $\begin{array}{c}0.1212 \\
(0.0431)^{* * *}\end{array}$ & $\begin{array}{c}0.1458 \\
(0.0464)^{* * *}\end{array}$ & $\begin{array}{c}0.0688 \\
(0.0394) *\end{array}$ & $\begin{array}{c}0.0903 \\
(0.0394) * *\end{array}$ \\
\hline Haussman & & & & 0.7548 & 0.0236 \\
\hline Wald & 0.0231 & 0.0264 & 0.0012 & 0.0014 & 0.0976 \\
\hline Obs & 276 & 276 & 276 & 276 & 276 \\
\hline
\end{tabular}

Source: Own elaboration. $* * *$ significance $<0.01 ; * *$ significance $<0.05$; *significance $<0.10$ 
Table 3

Pre-crisis panel data ordinary estimation

\begin{tabular}{|c|c|c|c|c|c|c|c|}
\hline $\mathrm{G}$ & I & II & III & IV & V & VI & VII \\
\hline c & $\begin{array}{c}2.030 \\
(0.6329)^{* * *}\end{array}$ & $\begin{array}{c}2.6891 \\
(0.3997)\end{array}$ & $\begin{array}{c}2.7637 \\
(0.6865)^{* * *}\end{array}$ & $\begin{array}{c}3.1465 \\
(0.6842)^{* * *}\end{array}$ & $\begin{array}{l}-0.5500 \\
(0.7460)\end{array}$ & $\begin{array}{c}2.3184 \\
(0.6552)^{* * *}\end{array}$ & $\begin{array}{c}3.8651 \\
(1.1125)^{* * * *}\end{array}$ \\
\hline $\mathrm{R}$ & $\begin{array}{c}0.0075 \\
(0.0213)\end{array}$ & & & & & & $\begin{array}{l}-0.0072 \\
(0.0356)\end{array}$ \\
\hline AI & & $\begin{array}{c}-0.0194 \\
(0.0095)^{* *}\end{array}$ & & & & & $\begin{array}{l}-0.1067 \\
(0.0753)\end{array}$ \\
\hline DC & & & $\begin{array}{c}-0.0064 \\
(0.0033)^{* *}\end{array}$ & & & & $\begin{array}{c}-0.0211 \\
(0.0093)^{* *}\end{array}$ \\
\hline DI & & & & $\begin{array}{c}-0.0451 \\
(0.0143)^{* * *}\end{array}$ & & & $\begin{array}{l}-0.0581 \\
(0.1066)\end{array}$ \\
\hline $\mathrm{RP}$ & & & & & $\begin{array}{c}0.0431 \\
(0.0197)^{* *}\end{array}$ & & $\begin{array}{c}0.2302 \\
(0.0738)^{* * * *}\end{array}$ \\
\hline DCP & & & & & & $\begin{array}{l}-0.0036 \\
(0.0038)\end{array}$ & $\begin{array}{c}0.0019 \\
(0.0123)\end{array}$ \\
\hline$S$ & $\begin{array}{l}0.03990 \\
(0.0296)\end{array}$ & $\begin{array}{c}0.0144 \\
(0.0296)\end{array}$ & $\begin{array}{c}0.0336 \\
(0.0298)\end{array}$ & $\begin{array}{l}-0.0022 \\
(0.0307)\end{array}$ & $\begin{array}{c}0.0398 \\
(0.0282)\end{array}$ & $\begin{array}{c}0.0307 \\
(0.0298)\end{array}$ & $\begin{array}{c}0.0022 \\
(0.0350)\end{array}$ \\
\hline $\mathrm{K}$ & $\begin{array}{c}0.0374 \\
(0.0361)\end{array}$ & $\begin{array}{c}0.0499 \\
(0.0363)\end{array}$ & $\begin{array}{c}0.0398 \\
(0.0370)\end{array}$ & $\begin{array}{c}0.0587 \\
(0.0370)^{*}\end{array}$ & $\begin{array}{c}0.1173 \\
(0.0407)^{* * *}\end{array}$ & $\begin{array}{c}0.0468 \\
(0.0366)\end{array}$ & $\begin{array}{c}0.1043 \\
(0.0465)^{* *}\end{array}$ \\
\hline Obs & 426 & 424 & 414 & 397 & 273 & 426 & 209 \\
\hline
\end{tabular}

Source: Own elaboration. $* * *$ significance $<0.01$; ** significance $<0.05$; *significance $<0.10$

Among fixed and random effects estimations on both cross-section and time causal relation between growth and financial variables is still negative for active interest, domestic credit and deposit interest as Table 4 shows. 
Table 4

Pre-crisis panel data with effects

\begin{tabular}{|c|c|c|c|c|c|}
\hline \multirow{2}{*}{$\mathrm{G}$} & Cross-section & Period & Cross-section and Period & Cross-section & Period \\
\hline & Fixed Effects & Fixed Effects & Fixed effects & Random Effects & Random Effects \\
\hline $\mathrm{c}$ & $\begin{array}{c}7.5408 \\
(2.0571)^{* * *}\end{array}$ & $\begin{array}{c}2.9212 \\
(1.1216)^{* * *}\end{array}$ & $\begin{array}{c}9.3842 \\
(1.9812)^{* * *}\end{array}$ & $\begin{array}{c}4.9742 \\
(1.4778)^{* * *}\end{array}$ & $\begin{array}{c}3.7093 \\
(1.0702)^{* * *}\end{array}$ \\
\hline $\mathrm{R}$ & $\begin{array}{l}-0.0162 \\
(0.0341)\end{array}$ & $\begin{array}{c}0.0191 \\
(0.0369)\end{array}$ & $\begin{array}{l}-0.0029 \\
(0.0333)\end{array}$ & $\begin{array}{l}-0.0091 \\
(0.0334)\end{array}$ & $\begin{array}{l}-0.0012 \\
(0.0343)\end{array}$ \\
\hline AI & $\begin{array}{l}-0.0511 \\
(0.0883)\end{array}$ & $\begin{array}{c}-0.2143 \\
(0.0786)^{* * *}\end{array}$ & $\begin{array}{c}-0.1570 \\
(0.0845)^{* *}\end{array}$ & $\begin{array}{l}-0.0780 \\
(0.0780)\end{array}$ & $\begin{array}{c}-0.1217 \\
(0.0721)^{*}\end{array}$ \\
\hline DC & $\begin{array}{c}-0.0491 \\
(0.0226)^{* *}\end{array}$ & $\begin{array}{c}-0.0326 \\
(0.0095)^{* * *}\end{array}$ & $\begin{array}{c}-0.0670 \\
(0.0218)^{* * *}\end{array}$ & $\begin{array}{c}-0.0273 \\
(0.0138)^{* *}\end{array}$ & $\begin{array}{c}-0.0226 \\
(0.0088)^{* * *}\end{array}$ \\
\hline DI & $\begin{array}{l}-0.0874 \\
(0.1226)\end{array}$ & $\begin{array}{c}0.1339 \\
(0.1144)\end{array}$ & $\begin{array}{c}0.1455 \\
(0.1213)\end{array}$ & $\begin{array}{l}-0.0638 \\
(0.1098)\end{array}$ & $\begin{array}{l}-0.0297 \\
(0.1023)\end{array}$ \\
\hline $\mathrm{RP}$ & $\begin{array}{c}0.1362 \\
(0.0735)^{* *}\end{array}$ & $\begin{array}{c}0.2895 \\
(0.0742)^{* * *}\end{array}$ & $\begin{array}{c}0.2029 \\
(0.0701)^{* * *}\end{array}$ & $\begin{array}{c}0.1681 \\
(0.0714)^{* * *}\end{array}$ & $\begin{array}{c}0.2372 \\
(0.0704)^{* * *}\end{array}$ \\
\hline DCP & $\begin{array}{c}0.0258 \\
(0.0233)\end{array}$ & $\begin{array}{c}0.0196 \\
(0.0128)\end{array}$ & $\begin{array}{c}0.0180 \\
(0.0239)\end{array}$ & $\begin{array}{c}0.0083 \\
(0.0172)\end{array}$ & $\begin{array}{l}-0.0046 \\
(0.0118)\end{array}$ \\
\hline S & $\begin{array}{l}-0.0694 \\
(0.0561)\end{array}$ & $\begin{array}{l}-0.0512 \\
(0.0377)\end{array}$ & $\begin{array}{c}-0.1844 \\
(0.0562)^{* * *}\end{array}$ & $\begin{array}{l}-0.0213 \\
(0.0428)\end{array}$ & $\begin{array}{l}-0.0047 \\
(0.0336)\end{array}$ \\
\hline K & $\begin{array}{c}0.0715 \\
(0.0467)\end{array}$ & $\begin{array}{c}0.1684 \\
(0.0504)^{* * *}\end{array}$ & $\begin{array}{c}0.1949 \\
(0.0550)^{* * *}\end{array}$ & $\begin{array}{c}0.0857 \\
(0.0451)^{* *}\end{array}$ & $\begin{array}{c}0.1119 \\
(0.0449)^{* * *}\end{array}$ \\
\hline Haussman & & & & 0.0540 & 0.7786 \\
\hline Wald & 0.0034 & 0.0019 & 0.0456 & 0.0672 & 0.0144 \\
\hline Obs & 209 & 209 & 209 & 209 & 209 \\
\hline
\end{tabular}

Source: Own elaboration. $* * *$ significance $<0.01$; $* *$ significance $<0.05$; *significance $<0.10$

Finally, in the post-crisis model negative impacts on growth rely on domestic credit, deposit interest and domestic credit to private sector when individual estimations are perfor- 
med. While real interest, domestic credit and domestic credit to private sector lead to lower economic growth rates in a jointly estimation, see Table 5.

Table 5

Post-crisis panel data ordinary estimation

\begin{tabular}{|c|c|c|c|c|c|c|c|}
\hline $\mathrm{G}$ & I & II & III & IV & V & VI & VII \\
\hline $\mathrm{c}$ & $\begin{array}{c}-1.5149 \\
(0.0941)^{*}\end{array}$ & $\begin{array}{c}-3.2512 \\
(0.8100)^{* * *}\end{array}$ & $\begin{array}{c}0.0199 \\
(0.7107)\end{array}$ & $\begin{array}{c}-2.9195 \\
(0.8995) * * *\end{array}$ & $\begin{array}{c}0.8358 \\
(1.5030)\end{array}$ & $\begin{array}{l}-0.1970 \\
(0.6926)\end{array}$ & $\begin{array}{l}-3.4757 \\
(4.3561)\end{array}$ \\
\hline $\mathrm{R}$ & $\begin{array}{c}0.1445 \\
(0.0624)^{* *}\end{array}$ & & & & & & $\begin{array}{l}-0.0294 \\
(0.1517)\end{array}$ \\
\hline AI & & $\begin{array}{c}0.1883 \\
(0.0361)^{* * *}\end{array}$ & & & & & $\begin{array}{c}0.2348 \\
(0.2672)\end{array}$ \\
\hline DC & & & $\begin{array}{c}-0.0134 \\
(0.0025)^{* * *}\end{array}$ & & & & $\begin{array}{l}-0.0040 \\
(0.0126)\end{array}$ \\
\hline DI & & & & $\begin{array}{c}-0.3566 \\
(0.0739)^{* * *}\end{array}$ & & & $\begin{array}{c}0.1371 \\
(0.2989)\end{array}$ \\
\hline $\mathrm{RP}$ & & & & & $\begin{array}{c}0.2738 \\
(0.1216)^{* *}\end{array}$ & & $\begin{array}{c}0.0664 \\
(0.2129)\end{array}$ \\
\hline DCP & & & & & & $\begin{array}{c}-0.0196 \\
(0.0036)^{* * *}\end{array}$ & $\begin{array}{l}-0.0076 \\
(0.0202)\end{array}$ \\
\hline $\mathrm{S}$ & $\begin{array}{c}0.0655 \\
(0.0374)^{*}\end{array}$ & $\begin{array}{c}0.0744 \\
(0.0288)^{* * *}\end{array}$ & $\begin{array}{c}0.0275 \\
(0.0278)\end{array}$ & $\begin{array}{c}0.0811 \\
(0.0310)^{* * *}\end{array}$ & $\begin{array}{c}0.0538 \\
(0.0444)\end{array}$ & $\begin{array}{c}0.0407 \\
(0.0279)\end{array}$ & $\begin{array}{c}0.0967 \\
(0.0653)\end{array}$ \\
\hline $\mathrm{K}$ & $\begin{array}{c}0.1091 \\
(0.0552)^{* *}\end{array}$ & $\begin{array}{c}0.1311 \\
(0.0430)^{* * *}\end{array}$ & $\begin{array}{c}0.1764 \\
(0.0426)^{* * *}\end{array}$ & $\begin{array}{c}0.1235 \\
(0.0442)^{* * *}\end{array}$ & $\begin{array}{l}-0.0004 \\
(0.0902)\end{array}$ & $\begin{array}{c}0.1818 \\
(0.0424)^{* * *}\end{array}$ & $\begin{array}{c}0.1392 \\
(0.1387)\end{array}$ \\
\hline Obs & 117 & 154 & 156 & 138 & 112 & 156 & 67 \\
\hline
\end{tabular}

Source: Own elaboration. $* * *$ significance $<0.01$; $* *$ significance $<0.05$; $*$ significance $<0.10$

In the post-crisis model only real interest and domestic credit to private sector remain with a negative impact on growth among fixed and random effects on both cross-section and time specifications. Active interest has negative impacts on growth only when fixed effects are considered as well as deposit interest, see Table 6. 
Table 6

Post-crisis panel data with effects

\begin{tabular}{|c|c|c|c|c|c|}
\hline & Cross-section & Period & Cross-section and Period & Cross-section & Period \\
\hline G & Fixed Effects & Fixed Effects & Fixed effects & $\begin{array}{c}\text { Random } \\
\text { Effects }\end{array}$ & $\begin{array}{c}\text { Random } \\
\text { Effects }\end{array}$ \\
\hline $\mathrm{c}$ & $\begin{array}{l}-13.1619 \\
(7.9549)^{*}\end{array}$ & $\begin{array}{c}-7.0182 \\
(4.3993) *\end{array}$ & $\begin{array}{l}-11.4776 \\
(7.3632)\end{array}$ & $\begin{array}{l}-3.4757 \\
(4.1521)\end{array}$ & $\begin{array}{l}-5.6994 \\
(4.1271)\end{array}$ \\
\hline $\mathrm{R}$ & $\begin{array}{c}-0.2884 \\
(0.1765)^{*}\end{array}$ & $\begin{array}{l}-0.1337 \\
(0.1308)\end{array}$ & $\begin{array}{c}-0.3417 \\
(0.1467)^{* * *}\end{array}$ & $\begin{array}{l}-0.0294 \\
(0.1446)\end{array}$ & $\begin{array}{l}-0.1092 \\
(0.1281)\end{array}$ \\
\hline AI & $\begin{array}{l}-0.3234 \\
(0.3503)\end{array}$ & $\begin{array}{c}0.4055 \\
(0.2312)^{*}\end{array}$ & $\begin{array}{l}-0.0379 \\
(0.3402)\end{array}$ & $\begin{array}{c}0.2348 \\
(0.2547)\end{array}$ & $\begin{array}{c}0.3494 \\
(0.2250)\end{array}$ \\
\hline DC & $\begin{array}{c}0.1369 \\
(0.0574)^{* *}\end{array}$ & $\begin{array}{c}0.0011 \\
(0.0113)\end{array}$ & $\begin{array}{c}0.0925 \\
(0.0541)^{*}\end{array}$ & $\begin{array}{l}-0.0040 \\
(0.0120)\end{array}$ & $\begin{array}{l}-0.0007 \\
(0.0109)\end{array}$ \\
\hline DI & $\begin{array}{l}-0.2007 \\
(0.3879)\end{array}$ & $\begin{array}{c}0.0985 \\
(0.2428)\end{array}$ & $\begin{array}{l}-0.1246 \\
(0.3197)\end{array}$ & $\begin{array}{c}0.1371 \\
(0.2849)\end{array}$ & $\begin{array}{c}0.1077 \\
(0.2422)\end{array}$ \\
\hline $\mathrm{RP}$ & $\begin{array}{c}0.3767 \\
(0.2630)\end{array}$ & $\begin{array}{c}0.1251 \\
(0.1938)\end{array}$ & $\begin{array}{c}0.5258 \\
(0.2588)^{* *}\end{array}$ & $\begin{array}{c}0.0664 \\
(0.2029)\end{array}$ & $\begin{array}{c}0.1312 \\
(0.1878)\end{array}$ \\
\hline DCP & $\begin{array}{c}-0.1482 \\
(0.0793)^{* *}\end{array}$ & $\begin{array}{l}-0.0107 \\
(0.0173)\end{array}$ & $\begin{array}{c}-0.1340 \\
(0.0725)^{*}\end{array}$ & $\begin{array}{l}-0.0076 \\
(0.0193)\end{array}$ & $\begin{array}{l}-0.0094 \\
(0.0170)\end{array}$ \\
\hline S & $\begin{array}{c}0.2271 \\
(0.1393)^{*}\end{array}$ & $\begin{array}{c}0.1053 \\
(0.0571)^{*}\end{array}$ & $\begin{array}{c}0.2358 \\
(0.1249)^{* *}\end{array}$ & $\begin{array}{c}0.0967 \\
(0.0622)\end{array}$ & $\begin{array}{c}0.0980 \\
(0.0558)^{*}\end{array}$ \\
\hline K & $\begin{array}{c}0.4786 \\
(0.2135)^{* *}\end{array}$ & $\begin{array}{c}0.2287 \\
(0.1309)^{*}\end{array}$ & $\begin{array}{c}0.4412 \\
(0.2197)^{* *}\end{array}$ & $\begin{array}{c}0.1392 \\
(0.1322)\end{array}$ & $\begin{array}{c}0.1980 \\
(0.1249)^{*}\end{array}$ \\
\hline Haussman & & & & 0.6352 & 0.0049 \\
\hline Wald & 0.0023 & 0.0043 & 0.0012 & 0.0977 & 0.0842 \\
\hline Obs & 67 & 67 & 67 & 67 & 67 \\
\hline
\end{tabular}

Source: Own elaboration. $* * *$ significance $<0.01 ; * *$ significance $<0.05$; *significance $<0.10$

Finally, the sample was split into efficient and not efficient financial systems in order to analyze the impacts on growth for the selected financial variables. Efficiency was fixed to the development index of each country, consequently efficient systems are Australia, Canada, 
Germany, Japan, Malaysia, Singapore, Switzerland, United Kingdom, United States; not efficient system the remaining countries. Negative impacts on Growth for financial variables like domestic credit, deposits interest and domestic credit to private sector still remain regardless the split in the sample, see Table 7. Furthermore, negative impacts are greater in efficient financial systems than in not-efficient ones.

Table 7

Efficient and not efficient panel data

\begin{tabular}{ccc}
\hline G & Efficient Financial System & Not Efficient Financial System \\
AI & n.s. & -0.06 \\
& & $(0.006)^{* *}$ \\
DC & -0.07 & -0.012 \\
& $(0.005)^{* *}$ & $(0.0005)^{* * *}$ \\
DI & -0.1396 & -0.0538 \\
& $(0.031)^{* * *}$ & $(0.008)^{* *}$ \\
RP & 0.1374 & 0.1815 \\
& $(0.02)^{* * *}$ & $(0.05)^{* * *}$ \\
DCP & -0.013 & n.s. \\
& $(0.0009)^{* * *}$ & 0.2002 \\
K & 0.2108 & $(0.02)^{* * *}$ \\
Wald & $(0.01)^{* * *}$ & 0.0231 \\
Obs & 0.0156 & 296 \\
\hline
\end{tabular}

Source: Own elaboration. $* * *$ significance $<0.01$; $* *$ significance $<0.05$; * significance $<0.10$. n.s means not significant.

Empirical evidence has proved the existence of negative impacts on growth from specific financial variables that can be considered as a measure for an inefficient financial market. During the empirical test was found that active interest, domestic credit, deposit interest and domestic credit to private sector variables inhibit economic growth. In other words, domestic credit has not been enough to generate dynamics on economic activities, at the same time active interest and deposit interest have negative impacts on growth. This causal relation financial variables and economic growth are consistent with the theoretical model develo- 
ped in previous sections. That is, capital yields detour capital flows from productive sector towards financial markets and thus generate a growing portfolio investment phenomenon. For economic growth to be fostered capital flows need to be allocated at productive sector as credit to producers. This is only possible if marginal product of capital is more attractive than capital yields within financial markets, otherwise growth will tend to diminish as empirical evidence has proved. Regarding the empirical tests, all estimations are consistent with panel data methodology as Beck (2009) proved.

\section{Discussion}

The existence of a relation between financial and real sector within an economy is very clear and is consistent with most specialized literature. Mechanisms of interaction between both sectors are found in credit constrains, capital yields and capital reallocations. As productive credit emerge when capital resources need to be reallocated through economic agents that need it for producing, negative effects on growth can take place since credit restrictions, high volatilities on capital yields or high credit costs appear and even tend to increase. On the other hand, high capital yields can also lead to a low growth because capital flows tend to be allocated where expected returns are the highest. In other words, financial markets can generate low economic growth rates. This result is consistent with Arcand et al. (2015), Aizenman et al. (2015) and Loayza et al. (2018) in the sense that further increases in financial development lead to lower economic growth rates.

Therefore, results prove that negative impacts on growth are present when considering whether a financial system is well developed or not. Lower economic growth rates are generated by missed reallocations of capital flows. If capital yields are higher than marginal product of capital, then reallocations will always go through portfolios investment thus leading to low economic growth.

Financial regulation can prevent the fall in the economic growth rate by applying a capital yield tax when capital goes to financial markets instead of productive sectors, result that supports previous studies performed by Barth, Caprio and Levine (2001a, 2001b, 2004, 2005), Levine (2011), La Porta, Lopez-de-Silanes and Shleifer (2005), even more they proved how financial regulations can corrects negative impacts from financial system; also consistent with Basel III.

At this point several ways of regulation emerge for discussion; for instance government can consider intervening by a bailouts, this type of regulations should be applied when financial system are at a high risk of bankrupt or because credit constrains are extremely elevated. Nevertheless the effect of a bank bailout on real economy is not conclusive: while Detragiache and Ho (2010) argue that state interventions relying on bailouts are associated to 
lower growth rates crisis, Honohan and Klingebiel (2003), Claessens et al (2005), Cecchetti et al. (2009) and Dell'Arriccia et al. (2008) found no effect or negative effect on real economy due to a state intervention. It is easy to imagine that a bank bailout may impact in a pervasive way since it can foster the growth of the stock index of a country and thus having a negative effect on productive credits and therefore on economic growth.

A very similar argument stands when considering a TBTF policy since implies a special protection from government on large banks in order to avoid failures; this policy can reduce the risk of banks and increase their values. Markets tend to react negatively to this kind of policy (Allen et al.2018), in respect to economic growth due to the false perception of strength form a bank with a TBTF policy because capital flows will invest within the bank's stocks or portfolios. Other way to regulate financial system is through a fractional reserve policy. Fractional reserves ensure availability of household savings so credit is possible, however banks with fractional reserves can suffer from runs and panics easily; imagine households can demand immediate payment in currency for their deposits in any bank, and then credit system could collapse due to the lack of guarantee money. Under this scenario credit constrains may appear leading to a inefficient policy, even more for this policy to be efficient reserve requirements would need to be $100 \%$ according to Chari and Phelan (2014).

The necessity of regulations has risen since a new view emerged suggesting that monetary policy alone cannot neutralize internal or external shocks on financial system, Farhi and Werning $(2012,2014)$ and Rey $(2015)$ showed that a type of capital controls or a macro-prudential policy need to be implemented. This new line of research is based on the phenomenon that financial frictions turn conventional monetary policy less effective, see Cespedes et al. (2004), Devereux et al. (2006), Gertler et al. (2007), Braggion et al. (2009). Capital controls are closer to behave like taxes on capital flows, they can correct externalities associated with credit constrains are therefore to constitute a second best optimal policy respond if conventional monetary policy fails as Bianchi (2011), Benigno et al. (2013), Bianchi and Mendoza (2010, 2018), Jeanne and Korinek (2010) suggest. In that sense regarding this research, government can raise the capital inflow tax to avoid sudden stops towards productive sectors, particularly in emerging markets where volatility and credits constrains impact with intensity, while trying to hold inflation low, but the rise will increase the expected capital price for the next period creating inflation and therefore false growth.

In this research, financial regulation is closer to the line of King (2012) and Caprio et al. (2014) regarding that a reasonable trade-off between financial stability and economic growth is necessary. Low economic growth rates are not desirable of course, so no matter if the financial system is well developed or not, the key is to guarantee capital yields to be lower than marginal product of capital. This can only be achieved by creating regulatory/ legal frameworks that limit portfolios investment. In here two possible policy implications 
emerge: a) to introduce a regulation in order to prevent capitals yields to be higher than marginal product of capital so a capital yield tax is not necessary, or b) to allow capital yields to be higher than marginal product of capital and introduce the regulation by creating the tax needed to reallocate capital flows on productive credits. Either way regulation would have the objective of avoiding economic growth rate to fall.

Regulation can be as Masciandaro and Passarelli (2013) would say a "sharp prohibition rule such as" all instruments whose yield is above of a given level are banned, that given level would be the marginal product of capital. This idea of regulation can be more progressive than taxation; its justification comes from the fact that banks meet regulations on risk by drastically cutting on their most toxic assets due to Basel III. So if government and banks could agree on the need of a trade-off between financial stability and economic growth, assets with capital yields above marginal product of capital could be considered as a kind of a "toxic" asset. Even with taxation, a bank may decide to keep assets with capital yields being above marginal product (if they make profits from them) and just pay the tax, then this resources would be reallocated on real sector as productive credits.

This behavior is been found when a financial portfolio has been characterized as toxic in terms of Systemic Risk Externalities (SRE), in fact there is a SRE tax and is more efficient than a generic financial tax according to Goodhart (2011) and Masciandaro and Passarelli (2013), since "can be calibrated to reduce the expected welfare produced by the financial activity" and "is forward looking and can affect the future behavior of the financial market participants while generic financial taxes are backward looking". Therefore the financial regulation that is been proposed in this research would have the intention of prevent financial institutions from issuing instruments with too much risk of generating low economic growth rates.

This idea is also consistent with the notion that interest rate are usually manipulated to achieve traditional macroeconomics goals, but a second instrument should complement the monetary policy in order to diminish financial risk accumulations, as Issing (2003) and Fahr and Fell (2017) addressed, since traditional monetary policies lead to trade-offs between objectives or even destabilize real economy and financial sector.

This notion has been discussed for a long time now, Keynes (1936) argued that excessive short-term trading could lead to speculative bubbles and should be discouraged through transactions taxes. Later on Tobin (1978) proved that a tax on foreign exchange could be implemented for reducing short-term international capital mobility and therefore inhibit instability between real and financial sectors. Then Stiglitz (1989) as well as Summers and Summers (1989) gave support to taxation as a way to prevent financial market failures. In a Pigouvian framework, taxation and regulation are equivalent and both policies can achieve a first-best outcome. 
As a final reflexion, most regulations if not all proposed by Basel III are extremely important in order to mitigate the negative impacts on growth when financial crisis emerge. Eliminating transmissions channels between real and financial sectors is highly recommended, in this sense improvement on administrative, operative and directive processes on risk management, individual exposures, bank exposures, corporate exposures, capital instruments, real estate transactions, domestic credit and so on, are necessary. Basel III also emphasizes micro and macro prudential behaviors; first one suggests bank regulations to decrease risk exposure and increase reaction capacities, second one recommends systemic risk to be constantly controlled to avoid long-term negative effects.

The research characterized in this document relays on both dimensions. Microfoundations in the model allows to analyze disaggregate effects on the economic fundamentals, when such effects are aggregated the model shows long-term behaviors on them also. Therefore prudential behaviors at individual levels lead to prudential behaviors at macroeconomic levels. Heterogeneity in the model is present across households but not across companies, consequently if banks allocate more capital into productive sector, financial system would tend to increase economic activities. Since the objective is to ensure high economic growth rates that lead to more employment, higher income and better quality of life, it is really necessary to allocate capital flows as productive credit. In this sense, the results highlighted in this research are consistent with Basel III recommendations.

\section{Conclusions}

This research shows that there is a natural link between real sector and financial markets, which is consistent with most specialized literature and according with financial crisis of 2008 . The relation between sectors can enhance or inhibit productive credits and therefore accelerate or slow economic growth. A very intuitive result this research gives is that productive credit will exist as long as marginal product of capital turns to be higher than capital yields and thus will lead to a full employment economic growth. Consequently economic growth rate can fall if capital reallocations do not go to borrower sector, which would be possible only when capital yields are higher than marginal productivity of capital.

Under this scenario, in order to prevent economic growth rate from falling a financial regulation can be implemented by creating regulatory/legal frameworks that limit portfolios investment. In here two possible policy implications emerge: a) to introduce a regulation in order to prevent capitals yields to be higher than marginal product of capital so a capital yield tax is not necessary, or b) to allow capital yields to be higher than marginal product of capital and introduce the regulation by creating the tax needed to reallocate capital flows on productive credits. Either way regulation would have the objective of avoiding economic 
growth rate to fall, idea consistent with Acharya (2009).

If regulation is introduced as an agreement between government and banks by considering banned instruments whose yield is above of marginal product of capital; or if regulation is implemented as taxation on "toxic" assets, then falls on economic growth rate can be avoided.

In any case, regulation needs to guarantee both lenders and borrower sectors to participate within economic activities as described in section 4; also, financial regulation needs to be applied only when marginal product of capital is lower than capital yield. When financial regulation corrects the negative impacts already defined, the economy returns to a sustained balanced growth path with full employment.

When productive credit constraints, missed reallocations of capital flows, or any other financial inefficiency is present, capital accumulation may be inhibited having a negative impact on real economy. This result is consistent with Benabou (1993, 1996), Durlauf (1996), Fernandez and Rogerson (1994, 1996), De Serres et al. (2006), Ulrich (2004) and Sinha (2012). Despite the missed reallocations, physical and human capital accumulations are still possible in the economy (even if only one sector is active) in accordance with Banerjee and Newman (1993) Galor and Zeira (1993), Aghion and Bolton (1997), Piketty (1997), Levine (1997), Levine and Zervos (1998), Rajan and Zingales (1998).

Empirical evidence corroborates the link between real economy and financial sector in accordance with Sinha (2012), and also that there is a negative impact on growth because high levels of capital yields. Capital accumulation enhances growth even when capital yields are higher than marginal productivity of capital within productive sectors. However, there is a point in which further increases in financial development lead to lower economic growth rates, result that is also consistent with Arcand et al. (2015), Aizenman et al. (2015) and Loayza et al. (2018). Methodology techniques used in this research performed exactly as Beck (2009), Blundell and Bond's (1998), Nickell (1981) and Barucci et al. (2019) described. Both theoretical an empirical result depends on assumptions set out through the investigation. Therefore the pending agenda relays on eliminating the most assumptions as possible, for instance analyze an open economic, to amplify the financial sector activities, to incorporate other taxes and consumption behaviors. From the empirical analysis, perspective is needed to perform regional estimations or to divide countries by type/size of financial sectors.

\section{References}

Acemoglu, D., P. Aghion, and F. Zilibotti, (2006), Distance to Frontier, Selection and Economic Growth. Journal of the European Economic Association, 4: 37-74. https://doi.org/10.1162/jeea.2006.4.1.37

Acharya, V., (2009), A Theory of Systemic Risk and Design of Prudential Bankregulation. Journal of Financial Stability, 5 (3), 224-255. https://doi.org/10.1016/j.jfs.2009.02.001 
Aghion, P. and P. Bolton, (1997), A Trickle Down Theory of Growth and Development, Review of Economic Studies, 64, 151-172. https://doi.org/10.2307/2971707

Aghion, P., P. Howitt, and D. Mayer-Foulkes, (2005), The Effect of Financial Development on Convergence. Quarterly Journal of Economics 120: 173-222. https://doi.org/10.3386/w10358

Aizenman, J., D. Park, and Y. Jinjarak, (2015), Financial Development and Output Growth

in Developing Asia and Latin America: A Comparative Sectoral Analysis. Cambridge: National Bureau of Economic Research. https://doi.org/10.3386/w20917

Allen K., K. Cyree, M. Whitledge and D. Winters, (2018), An Event Study Analysis of

too-big-to-fail after the Dodd-Frank act: Who is too big to fail? Journal of Economics and Business, 98, 19-31. https://doi.org/10.1016/j.jeconbus.2018.03.003

Arcand, J., E. Berkes, and U. Panizza, (2015), Too much finance? Journal of Economic Growth 20: 105-48. https:// doi.org/10.1007/s10887-015-9115-2

Banerjee, A. and A. Newman, (1993), Occupational Choice and the Process of Development, Journal of Political Economy, 101, 274-298. https://doi.org/10.1086/261876

Barth, J.R., Caprio, G. Jr. and R. Levine, (2001a), The Regulation and Supervision of Banks around the World: A New Database, In Litan, R.E. y R. Herring eds., Brooking-Wharton Papers on Financial Services. Brookings Institution, Washington, DC, 83-250. https://doi.org/10.1353/pfs.2001.0003

Barth, J.R., Caprio, G. Jr. and R. Levine, (2001b), Banking System around the Globe: Do Regulation and Ownership Affect Performance and Stability, In Mishkin, F.S. Ed., Prudential Supervision: What Works and What Dosen't, University of Chicago Press, Chicago, IL, 31-96. https://doi.org/10.1596/1813-9450-2325

Barth, J.R., Caprio, G. Jr. and R. Levine, (2004), Bank Regulation and Supervision: What Works Best? Journal of Financial Intermediation, 13, 205-248. https://doi.org/10.1016/j.jfi.2003.06.002

Barth, J.R., Caprio, G. Jr. and R. Levine, (2005), Rethinking Bank Supervision and Regulation: Until Angels Govern, Cambridge University Press, Cambridge, UK. https://doi.org/10.1017/cbo9780511753817.008

Barucci, E., T. Colozza and C. Milani, (2019), The Effect of Bank Bail-Outs in the EU, Journal of International Money and Finance, 95, 14-26. https://doi.org/10.1016/j.jimonfin.2019.03.004

Beck, T., (2009), The Econometrics of Finance and Growth. In Palgrave Handbook of Econometrics. Edited by Terence C. Mills and Kerry D. Patterson. London: Palgrave Macmillan, 180-209. https://doi. org/10.1057/9780230244405_25

Benabou, R. (1993), Workings of a City: Location, Education and Production, Quarterly Journal of Economics, 108, 619-652. https://doi.org/10.2307/2118403

Benabou, R, (1996), Equity and Efficiency in Human Capital Investment: The Local Connection, Review of Economic Studies, 62 (2), 237-264. https://doi.org/10.2307/2297851

Benigno, G., H. Chen, C. Otrok, A. Rebucci and E. Young, (2013), Financial Crises and Macro-prudential Policies, Journal of International Economy, 89 (2), 453-470. https://doi.org/10.1016/j.jinteco.2012.06.002

Bianchi, J. (2011), Overborrowing and System Externalities in the Business Cycle, American Economic Review, 101 (7), 3400-3426. https://doi.org/10.1257/aer.101.7.3400

Bianchi, J., and E. Mendoza, (2010), Overborrowing, Financial Crises and Macro-prudential Taxes, NBER working paper 16091. https://doi.org/10.3386/w16091

Bianchi, J., and E. Mendoza, (2018), Optimal time-consistent Macroprudential Policy, Journal of Political Economy, 126 (2), 588-634. https://doi.org/10.1086/696280

Blundell, R. and S. Bond, (1998), Initial Conditions and Moment Restrictions in Dynamic Panel Data Models, Journal of Econometrics, 87, 115-143. https://doi.org/10.1016/s0304-4076(98)00009-8

Braggion, F., L. Christiano and J. Roldos, (2009), Optimal Monetary Policy in a Sudden Stop, Journal of Monetary Economy, 56 (4), 582-595. https://doi.org/10.1016/j.jmoneco.2009.03.010

Carlin,W., and C. Mayer, (2003). Finance, Investment, and Growth. Journal of Financial Economics 69: 191-226. https://doi.org/10.1016/s0304-405x(03)00112-0 
Caprio, G., V. D’Apice, G. Ferri and G. Puopolo, (2014), Macro-financial Determinants of the Great Financial Crises: Implications for Financial Regulation, Journal of Banking and Finance, 44, 114-129. https://doi.org/10.1016/j.jbankfin.2014.03.001

Chari, V.V. and C. Phelan, (2014), On the Social Usefulness of Fractional Reserve Banking, Journal of Monetary Economics, 65, 1-13. https://doi.org/10.1016/j.jmoneco.2014.04.008

Cecchetti, S., M. Kohler and C. Upper, (2009), Financial Crises and Economic Activity, NBER working paper 15379.m https://doi.org/10.3386/w15379

Cespedes, L., R. Chang and A. Velasco, (2004), Balance Sheets and Exchange Rates Policy, Journal of Monetary Economics, 94 (4), 1183-1193. https://doi.org/10.3386/w7840

Claessens, S., D. Klingebiel and L. Laeven, (2005), Crisis Resolution, Policies and Institutions: Empirical Evidence, Systemic Financial Crisis: Containment and Resolutions, Cambridge University Press, 169-194. https://doi. org/10.1017/cbo9780511528521.007

De Serres, A., Kobayakawa S., Sløk T. and Vartia L. (2006), Regulation of Financial Systems and Economic Growth, OECD Economics Department Working Papers, No. 506, OECD Publishing. https://doi. org/10.1787/870803826715

Dell'Arriccia, G., E. Detragiache and R. Rajan, (2008), The Real Effect of Banking Crises, Journal of Financial Intermediation, 17(1), 89-112. https://doi.org/10.1016/j.jfi.2007.06.001

Demirgüc-Kunt, A., and R. Levine, (2001), Financial Structure and Economic Growth: A Cross-Country Comparison of Banks, Markets, and Developpement. Cambridge: MIT-Press. https://doi.org/10.7551/mitpress/3001.003.0003

Detragiache, E. and G. Ho, (2010), Responding to Banking Crises: Lessons from Cross-Country Evidence, IMF working paper 18. https://doi.org/10.5089/9781451962239.001

Devereux, M., P. Lane and J. Xu, (2006), Exchange Rates and Monetary Policy in Emerging Markets Economies Economic Journal, 116 (511) 478-506. https://doi.org/10.1111/j.1468-0297.2006.01089.x

Devereux, M., E. Young and C. Yu, (2019), Capital Controls and Monetary Policy in Sudden-Stop Economies, Journal of Monetary Economics, 103, 52-74. https://doi.org/10.1016/j.jmoneco.2018.07.016

Durlauf, S. (1996a), A Theory of Persistent Income Inequality, Journal of Economic Growth, Vol. 1, No. 1, 75-94. https://doi.org/10.1007/bf00163343

Fahr S. and J. Fell, (2017), Macroprudential Policy-closing the Financial Stability Gap, Journal of Financial Regulation and Compliance, 25 (4), 334-359. https://doi.org/10.1108/jfrc-03-2017-0037

Farhi E., and I. Werning, (2012), Dealing with the Trilemma: Optimal Capital Controls with Fixed Exchange Rates, NBER working paper 18199. https://doi.org/10.3386/w18199

Farhi E. and I. Werning, (2014), Dilemma not Trilemma? Capital Controls and Exchange Rates with Volatile Capital Flows, IMF Economic Review, 62(4), 569-605. https://doi.org/10.1057/imfer.2014.25

Fernández, R. and R. Rogerson, (1994), Public Education and the Dynamics of Income Distribution: A Quantitative Evaluation of Education Finance Reform, NBER Working Paper 4883.

Fernández, R. and R. Rogerson, (1996), Income Distribution, Communities and the Quality of Public Education, Quarterly Journal of Economics, 111, 135-164. https://doi.org/10.2307/2946660

Galor, O. and J. Zeira, (1993), Income Distribution and Macroeconomics, Review of Economic Studies, 60, 35-52. https://doi.org/10.2307/2297811

Gertler, M., S. Gilchrist and F. Natalucci, (2007), External Constrains on Monetary Policy and the Financial Accelerator, Journal of Money, Credit and Banking, 39, 295-330. https://doi.org/10.1111/j.0022-2879.2007.00027.x

Goodhart, C., (2011), The Emerging New Architecture of Financial Regulation, CFS working paper 2011/12, Frankfurt. Disponible en: https://econpapers.repec.org/paper/zbwcfswop/201112.htm

Honohan, P. and Klingebiel D., (2003), The Fiscal Cost Implications of an Accommodating Approach to Banking Crises, Journal of Banking and Finance, 27(8), 1539-1560. https://doi.org/10.1016/s0378-4266(02)00276-5

Issing, O. (2003), Monetary and Financial Stability, Tech. Rep. International Monetary Fund. Disponible en: https:// www.bis.org/review/r030331f.pdf 
Jeanne, O., and A. Korinek, (2010), Excessive Volatility in Capital Flows: a pigouvian Taxation Approach, American Economic Review, 100 (2), 403-407. https://doi.org/10.1257/aer.100.2.403

Keynes, J.M. (1936), The general Theory of Employment, Interest and Money, Macmillan. https://doi. org $/ 10.2307 / 2143949$

King, M. (2012), Twenty Years of in Inlfation Targeting, London School of Economics: Bank of England. Disponible en: https://www.bis.org/review/r121010f.pdf

Kivanc, K and S. Yildirim, (2019), How Does Financial Development Alter the Impact of Uncertainty? Journal of Banking and Finance, No. 102, pp. 33-42. https://doi.org/10.1016/j.jbankfin.2019.03.008

La Porta, R., López-de-Silanes, F. and A. Shleifer, (2005), What Works in Security Laws? Journal of Finance, 53, pp.23-45 https://doi.org/10.1111/j.1540-6261.2006.00828.x

Levine, R. (1997), Financial Development and Economic Growth: Views and agenda. Journal of Economic Literature 35: 688-726. https://doi.org/10.1596/1813-9450-1678

Levine, R. (2005), Finance and Growth: Theory and Evidence. London: Elsevier B. V, pp. 865-934.Levine R. (2011), Finance, Regulation and Inclusive Growth, in OECD and The World Bank, Promoting Inclusive Growth: Challenges and Policies, OECD Publishing, Paris. https://doi.org/10.3386/w10766

Levine, R., and S. Zervos, (1998), Stock Markets, Banks, and Economic Growth. American Economic Review 88: 537-58. https://doi.org/10.1596/1813-9450-1690

Loayza, N., A. Ouazad, and R. Rancière, (2018), Financial Development, Growth, and Crisis: Is There a Trade-Off? Cambridge: National Bureau of Economic Research. https://doi.org/10.3386/w24474

Masciandaro, D. and F. Passarelli, (2013), Financial systemic risk: Taxation or regulation? Journal of Banking and Finance, 37, 587-596. https://doi.org/10.1016/j.jbankfin.2012.09.020

Merton R, and Z. Bodie, (1995), A Conceptual Framework for Analyzing the Financial Environment, Harvard Business School, Working paper No. 95-062. Disponible en: https://www.researchgate.net/publication/228224831_A_Conceptual_Framework_for_Analyzing_the_Financial_Environment

Nickell, S. (1981), Biases in Dynamic Models with Fixed Effects, Econometrica, 49, 1417-1426. https://doi. org/10.2307/1911408

Piketty, T. (1997), The Dynamics of Wealth Distribution and the Interest Rate with Credit Rationing, Review of Economic Studies, 64, 173-189. https://doi.org/10.2307/2971708

Rajan, R., and L. Zingales, (1998), Financial Dependence and Growth. American Economic Review 88: 559-86. https://doi.org/10.3386/w5758

Rey, H. (2015), Dilemma not Trilemma: The Global Financial Cycle and Monetary Policy Independence, NBER working paper 21162. https://doi.org/10.3386/w21162

Rivas-Aceves S., (2012), ¿Puede la regulación financiera fomentar el crecimiento económico? Revista Argumentos, Universidad Autónoma Metropolitana, Xochimilco, México, No. 70, pp. 149-166. Disponible en: http://www. scielo.org.mx/scielo.php?script=sci_arttext\&pid=S0187-57952012000300008\&lng=es\&nrm=iso

Rivas-Aceves S. and Chiara Amato, (2017), Government Financial Regulation and Growth, Investigación Económica, Universidad Nacional Autónoma de México, Vol. 76, No. 299, pp. 51-86. https://doi.org/10.1016/j. inveco.2016.09.001

Rousseau, P. and P. Wachtel, (1998), Financial Intermediation and Economic Performance: Historical Evidence from five Industrial Countries. Journal of Money, Credit and Banking 30: 657-78. https://doi.org/10.2307/2601123

Sinha Anad (2012), Financial sector regulation and implications for growth, Bank for international settlements, BIS Papers No.62G. Disponible en: https://www.bis.org/publ/bppdf/bispap61g.pdf

Stiglitz, J. (1989), Using Tax Policy to Curb Speculative Short-term Trading, Journal of Financial Services Research, 3, 101-115. https://doi.org/10.1007/bf00122795

Summers L. and V. Summers, (1989), When Financial Markets work too well: A Cautious Case for a Securities Transactions Tax, Journal of Financial Services Research, 3, 261-286. https://doi.org/10.1007/bf00122806

Tobin, J. (1978), A Proposal for International Monetary Reform, Eastern Economic Journal 4, 153-159. Disponible en: https://web.holycross.edu/RePEc/eej/Archive/Volume4/V4N3_4P153_159.pdf 
Ulrich Thießen (2004), Financial system development, regulation and economic growth: Evidence from Russia, European review of economics and finance, Lisbon, 3(3), p. 169-202. Disponible en: https://ideas.repec.org/p/ diw/diwwpp/dp400.html

World Bank (2019), Economic and Financial Indicators http://datos.bancomundial.org/indicador, recovered on 11th January 2019. 